New Zealand journal of industrial relations, 1987, 12, 161-168

\title{
Compulsory arbitration and the state sector
}

\author{
Herbert Roth*
}

"Nothing in this Act shall apply to Her Majesty the Queen, or any department of the Government of New Zealand", said section 91 of the original Industrial Conciliation and Arbitration Act of 1894 , but there was a saving sentence "except as herein is otherwise expressly provided". What was expressly provided was spelled out in Part IV, sections 82 to 84 , which applied the act to the government railways. This raises two questions: Why were railwaymen included in a measure which otherwise applied to the private sector only? and, why were railwaymen the only government employees covered by the arbitration act? My paper addresses these questions and reaches the conclusion that fear of a national transport strike was the main reason for the inclusion of railwaymen, though the reasons for the exclusion of other government employees are less clear-cut. The paper then explores the attitudes of state employee organisations to the compulsory arbitration system up to the establishment of the first wagefixing tribunal in the state sector, patterned on the Arbitration Court, in 1944, and concludes with a brief survey of more recent developments.

Arbitration and conciliation as a means of settling industrial disputes had been discussed in New Zealand before 1890 , but there was a new sense of urgency after the crippling Maritime Strike of that year. This strike, which was until then by far the largest industrial conflict in New Zealand history, ended in total defeat for the unions which had joined it - mainly seamen, miners and watersiders - and the extinction of the Maritime Council which had directed it. The Maritime Strike, wrote Holt, "was a shock for the possessing classes in New Zealand. The goals of the Maritime Council might be modest but its means were frightening enough, since it had threatened to close down virtually the country's entire transport system" (Holt, 1986, p. 21). The danger the strike had posed was not quickly forgotten.

The Amalgamated Society of Railway Servants (ASRS) was affiliated to the Maritime Council. It did not join the strike, but it instructed its members not to do work normally done by striking watersiders. The Railway Commissioners, who were then in control of the government railways, insisted however that railwaymen handle coal at Westport and Lyttelton. The men who refused were dismissed (in Westport nearly the entire staff), together with four executive members of the ASRS in Christchurch, who were accused of having "counselled disobedience". A major reason for the failure of the ASRS to call out its members was a belief that the Commissioners were seeking to provoke a rail strike with the purpose of crushing the society and withdrawing concessions made earlier. The ASRS executive was also concerned over the loyalty of members, for there were reports that railwaymen in several centres would not support a strike. The executive's cautious approach did not prevent the Commissioners from withdrawing recognition from the ASRS. They refused to have any further dealings with the society unless it cut its ties with the Maritime Council and other outside unions, confined its membership to railway employees, allowed railwaymen to join or withdraw from the union at will, and made other specified changes to its rules.

There was disagreement in Parliament (in 1893) on whether the "determined stand" of the Commissioners had prevented a general rail strike, or whether on the contrary the highhanded actions of the Commissioners had pushed the railwaymen to the verge of striking. which was prevented only by "the coolness, the determination and good sense" of the ASRS executive officers (Parliamentary Debates v. 82 p. 458,20 Sept. 1893). What is not in dispute is that 
there was widespread concern about the possibility of a nationwide rail strike, described by Pember Reeves, the Minister of Labour, as "perhaps one of the greatest industrial dangers which may threaten the people of New Zealand" (ibid v. 77 p. 32, 12 Aug 1892). When Reeves first put forward an Industrial Conciliation Bill in 1891, he included a section which brought the Railway Commissioners and the ASRS within the scope of the proposed compulsory arbitration system. A parliamentary committee expressed the view in 1892 that the railways should be covered by compulsory arbitration regardless of "whether the railways remain under the control of a non-political Board or whether they are again placed under political management" (ibid v. 78 pp. 729-30, 6 Oct 1892).

Opposition to the inclusion of the government railways in the Arbitration Act came from the conservative opponents of the government, who still held a majority in the Legislative Council, and from the Railway Commissioners. The three Railway Commissioners had been appointed in 1889 under a Government Railways Act, which gave them absolute control free from ministerial interference. As regards staff, they had authority to engage or remove employees "as they think necessary", and to pay salaries, wages and allowances "as they shall from time to time determine". The government which had appointed them was defeated in the 1890 elections when a new Liberal government took over, but the Commissioners had a five-year term of office and they resented any curtailment of their powers.

In their annual report for 1891, the Commissioners wrote that they had:

found it necessary to decline to discuss the affairs of the employees with any persons outside the railway service. The Government Railways Act constitutes the Commissioners the tribunal to see that proper service is exacted from the employees on the one hand, and that fair treatment is accorded to them on the other. The interference of both well-intentioned persons and agitators is mischievous and injurious to efficient and safe conduct of the public service, and should not therefore be countenanced (Appendix to the Journals of the House of Representatives D-2, sess II, 1891, p. 3).

The Commissioners reinstated the strikers dismissed in 1890 , but only "as vacancies occurred", which meant in different posts and at lower wages than they had previously received. The men moreover had to sign a declaration that they would have nothing to do with the ASRS, and other new employees too had to give such an undertaking. There was pressure on existing staff members to resign from the ASRS or miss out on pay rises and promotions. The Commissioners refused leave to ASRS delegates to attend the society's annual conferences, and they persisted in their refusal to accept any communication from the ASRS.

The Commissioners nevertheless failed to destroy the ASRS. The society's membership declined sharply between 1890 and 1893, but the Commissioner's autocratic exercise of their powers turned public opinion against them, as it turned against employers generally. "The sympathy which at first had been widely felt for the attacked masters now to some extent transferred to the defeated men", wrote Reeves (Reeves, 1902,v. 2 p. 96). The ASRS accepted the Commissioners' terms for a resumption of recognition in July 1894, but a month later Parliament at last passed the Industrial Conciliation and Arbitration measure which Reeves had put forward year after year since 1891, and which the ASRS fully supported.

The sections of the new act referring to the government railways provided that the Amalgamated Society of Railway Servants could register as an industrial union and that the Railway Commissioners were deemed to be employers within the meaning of the act. They were empowered to make industrial agreements with the ASRS, and both sides were entitled to refer unresolved disputes of sufficient gravity to the Arbitration Court for hearing and determination. Such disputes had to be referred directly to the Arbitration Court, and not through the intermediary of local Boards of Conciliation. If the Commissioners refused to agree to refer a dispute for determination, the Court had the power to require (the 1891 draft had said "to compel") the Commissioners to appear before it.

The Commissioners thus ceased to be the final "tribunal" of employment conditions in the railway service, which they had claimed to be, and they were forced to accept not only the interference but also the arbitration of a third party, something which they had denounced earlier as "mischievous and injurious" to the service. As it happened however, the Commissioners never suffered this indignity because in October 1894 Parliament passed a Government Railways Act, which abolished the Board of Commissioners and placed the railways under direct ministerial control. On the day the Arbitration Act came into force, 1 January 1895 , the Commissioners ceased to control the railways.

The main reason for the inclusion of the railway service in the arbitration system was clearly the desire to avert another threat of a rail strike, but the Liberal government was 
probably influenced also by a wish to curry favour with railwaymen. As Holt points out, the government railways constituted by far the largest commercial enterprise in the country. with a staff of about 5000 men. This raises the question why railway men were the only group of state employees to be covered by compulsory arbitration. In 1892, during a debate on Reeves's Industrial Conciliation Bill, a conservative member moved that "the Departments of Public Works. Education. Defence, and Justice shall also be deemed to be industries within the meaning of this Act, and all the provisions of this Act shall apply to them" (Parliamentary Debates v. 78 p. 131. 15 Sept 1892). This proposal was rejected by the government majority but, as the proceedings were in committee, the discussion was not reported in Hansard.

Reeves may have wished to include all government employees, but realised that this would not be acceptable to the Legislative Council. Presumably the gentlemen who staffed clerical departments were not seen as likely victims of industrial agitators, though there had been a strike of telegraph operators in 1880 . The railways were more obviously an "industry" and conflict was more likely there than in other sectors of state employment. Another reason for not including civil servants must have been that ministers wished to keep control of the wage bill. and were anxious to retain the political advantages that went with the power to improve salaries and conditions for state employees.

In 1895 another railway union gained recognition, the Railway Officers Institute (ROI). which represented salaried officers in the service. The ROI discussed registration under the Arbitration Act on the same lines as the ASRS. In July 1897 it asked the department whether there was any objection to this, but registration was not approved and the ROI was incorporated under the Unclassified Societies Registration Act (New Zealand Railway Officers Advocate p. 156. Sept-Oct 1970). I do not know what reasons the department gave for its refusal, but I assume that it drew a distinction between the manual, wage-worker membership of the ASRS and the administrative and clerical, white-collar members of the ROI, who were more akin to salaried public servants.

The ROI therefore had no access to the compulsory arbitration machinery, but the ASRS which had this right preferred to deal directly with the minister and with the department. Alfred Cadman, the new Minister for Railways, had represented goldfields electorates through most $o^{r}$ his parliamentary career and was sympathetic to the claims of labour. The long economic depression moreover was coming to an end in the mid 1890s and the Government was able to make concessions. The Government Railways Act of 1894, which abolished the Commissioners, also set up appeal boards with staff representation. Two years later, a Government Railways Department Classification Act for the first time classified the service. It incorporated the appeal boards and raised rates of pay. Further pay increases followed in 1897. and in 1899 the government granted a special allowance of sixpence per day to men on the minimum rate of $6 \mathrm{~s} 6 \mathrm{~d}$. A new Classification Act in 1901 incorporated this allowance and raised other rates as well.

The ASRS had good reason therefore to be satisfied with its dealings with the minister. and no cause to seek the intervention of the Arbitration Court. There were some problems however. The Arbitration Court too was raising wages in the later $1890 \mathrm{~s}$, and tradesmen in particular gained higher rates from the court than were paid in the railway workshops. In the case of carpenters, for instance, the Arbitration Court in 1897 set a daily rate of $10 \mathrm{~s}$ in the Canterbury district, but the carpenters maximum rate under the Railways Classification Act was only 9s.

This discrepancy between ruling rates for tradesmen and the rates paid in the railways workshops was not a new grievance. In 1890 an ASRS witness had complained to the Sweating Commission that "the government take advantage of being regular employers to give less wages than other employers. Joiners get $9 \mathrm{~s}$ a day - outside 10 s is the wage" (Appendix to the Journals of the House of Representatives H-5, 1890, p. 87). The Arbitration Act introduced a new element however, and the question was asked in Parliament whether carpenters employed in the Addington railway workshops were legally entitled to the 10 s rate, seeing that the railway service was covered by the Arbitration Act.

Cadman replied in the negative. There was, he said, a recognised society in the railway service, and if that society had any grievance it could go to the Arbitration Court. The Court had jurisdiction between the Railways Department and the ASRS, and had power to deal with any dispute between them. What had happened however, was not that the ASRS had referred a dispute to the court. but that outside unions were, as Cadman put it, "anxious to virtually interfere between the department and its own recognised society" (Parliamentary Debates v. 100 p. 245, 1 Dec 1897). He also pointed out that pay rates in the Classification Act were uniform throughout the country, and could not be easily adjusted any time an outside union gained 
higher rates in a particular district. Nevertheless, he promised to consider changes to the Classification Act to remedy "one or two seeming anomalies", and an amendment act in 1897 raised carpenters' rates to a maximum of 10 s per day.

Pressure to bring government employees under the Arbitration Act came from several quarters. Most government tradesmen, such as printers in the Government Printing Office or boilermakers in the railway workshops, belong to their craft unions rather than to a state employee organisation, and the small tradesmen's unions, which dominated the Trades and Labour Councils, wanted their members in state employment to enjoy the higher rates prescribed in Arbitration Court awards. Some of the more radical government MPs gave their support in Parliament, while opposition MPs used the opportunity to exploit divisions in the Liberal ranks. "Those who are opposed, and who always have been opposed, to the labour legislation", commented Dick Seddon, the Prime Minister, "are most strenuous in saying that this legislation should apply to the Government, and by this means are endeavouring to injure this legislation and, by injuring it, hope to ultimately succeed in wiping it off the statute-book" (ibid v. 119 p. 912,30 Oct 1901 )

Seddon's position was quite different from Reeves's, for he did not want any state employees brought under the Arbitration Act. "You cannot divest (the government) of the constitutional position", he told Parliament, "namely that the representatives of the people have the control of the purse of the colony, and give it to a Board or Court to fix what is to be paid, and to make a claim or cast a burden upon the taxpayers of the country" (ibid v. 119 p. 911,30 Oct 1901). The ASRS also opposed outside arbitration because it was satisfied that its members got a better deal under the classification system, through direct negotiations with their minister.

In 1898 the annual conference of Trades and Labour Councils resolved that awards of the Arbitration Court should be binding on all mem employed by the government "in the particular trade affected" (Annual Conference of Trades and Labour Councils of New Zealand, 1898. p. 7). The 1899 conference repeated this request, as did the conference in 1900 . The Councils did not, at that time, propose to bring all government employees within the scope of the Arbitration Act. However, when Parliament discussed a new Industrial Conciliation and Arbitration Bill in 1900, the Labour Bills Committee proposed to strike out the clause which exempted the Crown from the scope of the act, but this met with strong opposition from Seddon and from Joseph Ward, the new Minister for Railways. Liberal members split on this issue and the conservative opposition gleefully supported the rebels. "Is it fair", asked James Allen, the conservative member for Bruce, "that the government should be allowed to employ labour at different rates from those which a private employer has to give? There can be no argument at all, as far as I can see, in favour of leaving the government out of this act" (Parliamentary Debates v. 113 p. 259,28 Aug 1900 ).

The Government suffered a narrow defeat when the House voted to add to the definition of "employer" the words" and shall include the Crown and every department of the Government of New Zealand; provided that the appropriations to the service of Her Majesty shall not be increased by any award under this Act". Seddon was able to retrieve the position somewhat by gaining approval by an amendment which provided "that the term "employer" in this subsection shall not apply to the Minister for Railways or Postmaster-General, inasmuch as the employees in the Railways and Post and Telegraph Branches of the public service are under classification by special acts" (ibid v. 113 p. 557.7 Sept 1900). The House then voted, at $40^{\circ}$ clock in the morning, to reinsert the clause which exempted the Crown altogether, which meant that the definition of "employer" was in contradiction to the text of the bill, but the confusion was eventually sorted out and, as finally passed, the act restored the status quo and defined "employer" without any reference to the Crown or to government departments.

The 1900 Arbitration Act included a revised and amplified section dealing with the government railways (s 109). It empowered the Minister for Railways to "from time to time enter into industrial agreements with the registered society in like manner in all respects as if the management of the government railways were an industry, and he were the employer of all workers employed therein" and provided that "if any industrial dispute arises between the Minister and the society it may be referred to the Court for settlement". In making an award under this section, however, the Arbitration Court was now required to "have regard to the schedule to "The Government Railways Classification Act, 1896." The ASRS also gained the right to make recommendations for the appointment of the workers' member of the Arbitration Court though, except for the purpose of making an award, the Court was to have no jurisdiction over the society.

The Government had proposed a clause which required the Minister for Railways' consent 
before the ASRS could refer a dispute to the Arbitration Court, but this was struck out by the Labour Bills Committee (ibid v. 113 p. 680, 13 Sept 1900). Ward however vigorously opposed any interference by the Arbitration Court. Parliament, he claimed, "is the conciliation and arbitration court for the officers and employees of the State departments of this colony. Here is the power to increase their salaries; here is the power to give them further concessions for the purpose of placing them on a higher level, if it is thought desirable to do so. This Parliament is also the Court to adjust salaries and wages if it so decides" (ibid v. 113 p. 679, 13 Sept 1900).

The Trades and Labour Councils returned to the attack at their 1901 conference, with a motion "That the Government be urged to bring all its employees under the scope of the Conciliation and Arbitration Act" (Trades and Labour Council of New Zealand, 1901, p. 10). This was carried, but not without opposition. Government employees, claimed one delegate. were considerably better off than the workers employed by private employers, and they had no grievances and did not desire to be brought under the provisions of the act. Another delegate however reported that the Dunedin Painters Union had had a good deal of trouble with men at the Hillside railway workshops, where they worked for $1 \mathrm{~s}$ and $1 \mathrm{~s} 6 \mathrm{~d}$ a day less than the painters' rate in town, and the chairman of the conference, a West Coaster, expressed the opinion "that the present so-called Liberal Government were the greatest sweaters in the colony" (ibid p. 110).

The conference also resolved to appoint a deputation to wait on the Minister for Railways to request him to give preference to union members in appointments to the railway service. This suggests that union members were anxious to enter the service despite the lower rates paid there. The advantages of a "government billet" were secure employment, paid holidays, compensation for accidents (albeit at the discretion of the department), and such staff privileges as free rail passes.

There is no evidence of any widespread discontent among railway employees, but some Liberal members, mostly from Christchurch. kept urging the government to place the railway service fully under the Arbitration Act. In July 1901 Ward told Parliament that the staff themselves would have an opportunity to decide the issue. "The men in the workshops", he explained, "are to some extent in a different position from the other railway employees. The Government has considered the matter carefully, and, if the men in the workshops would prefer to come entirely out of the classification scheme and be dealt with under the Conciliation and Arbitration Act, the Government have no objection to that" (Parliamentary Debates v. 116 p. 137.5 July 1901$)$.

A poll was to be taken of workshop staff. A departmental circular pointed out that a vote for arbitration meant the loss of all staff privileges now enjoyed, and the ASRS urged its members to stick to the present pay-fixing system. "Had you been under Arbitration for the past ten years," wrote the ASRS general secretary, "you would not have been able to congratulate the Society, as you can now, upon having put considerably more than a quarter million pounds of money into your pockets than would have been the case under old conditions prevailing prior to $1890^{\prime \prime}$ (New Zealand Railway Review p. 1. July 1901). The result of the ballot, taken on 21 August 1901, was an overwhelming vote of 1325 in favour of retaining the present system, with only 82 votes in favour of the Arbitration Act (Parliamentary Debates v. 118 p. 1, 29 Aug 1901).

The workshops vote cut the ground from under the opponents of the classification system, and the passing of the Government Railways Superannuation Fund Act in 1902 helped to consolidate government support among the staff. The ASRS had been very anxious to maintain the classification system, but this did not prevent it from using the threat of arbitration to press the department for further concessions. In 1904, for instance, speakers at the biennial ASRS conference claimed that the workshops vote had not been representative because it covered only part of the total railway staff. If a vote of all employees were taken today, they claimed, they would almost unanimously decide to come under the Arbitration Act, because the department had failed to redress their grievances and had withdrawn privileges, such as first-class rail passes for all and full-time pay compensation for accidents.

In 1905 a Dunedin member once again put a question in Parliament about bringing government employees under the Arbitration Act, but Seddon replied blandly that the question opened up a very large subject and that such a step should not be taken without due consideration (ibid v. 132 p. 245, 5 July 1905). In April 1906 the Government introduced an eight-hour day in the railways, without loss of pay, which effectively pacified the staff for some years to come. When railway tradesmen again agitated for higher pay, the Minister for Railways, early in 1910, offered to conduct another ballot on putting staff under the Arbitration 
Act, but the ASRS rejected the proposal.

Meanwhile another group of manual workers had become government employees when Parliament passed the State Coal-Mines Act in 1901. The first state colliery was the Mokihinui mine, near Seddonville on the West Coast, and the act provided that "any award under the Industrial Conciliation and Arbitration Act, 1900 relating to coal-mines in the industrial district in which any State coalmine is situated shall, subject to such variations as in the opinion of the Court are necessitated by local circumstances, apply to such State coal-mine" (s 18).

This clause was not in the original draft of the bill. When Seddon introduced the State Coalmines Bill in October 1901, he countered opponents who feared an extension of state patronage and extravagance by promising that men working in the state mines "will not be receiving any more than they are receiving from the private coal-mine owners" (ibid v. 119 p. 682, 23 Oct 1901), but the bill gave no details on how this was to be implemented. An opposition member moved that the state mines be brought under the Arbitration Act but the government majority defeated this proposal and, on Seddon's motion, added the clause quoted above. According to Seddon, it meant that the minister in charge of state coal mines had to take as his guide in setting wage rates the awards covering private mines in the same district.

This clause was repeated in the Coal-mines Acts Compilation Act of 1905 (s 115), but it was badly worded because there were several different coal-mining awards in force in the Westland industrial district. Each mine had its own union and its own award, and the question was asked, which of these Westland awards should apply to the Seddonville colliery. The Arbitration Court considered this problem in 1905 and decided to add the state coal mine to a pending dispute at the Denniston mine (Book of Awards v. 6 p. 29, 1905). However, when the court issued an award for Seddonville in February 1906, it was based not on Denniston but on an earlier Granity Creek award "with such modifications and variations thereof as are necessitated by local circumstances" (ibid v. 7 p. 168, 1906). In 1907 the Arbitration Court issued a new award for the Seddonville mine, but Judge Sim pointed out in a memorandum that while he had followed the form of the earlier award, there was some legal doubt about the whole procedure (ibid v. 8 pp. 1064-65, 1907).

The issue was clarified in the Coal-mines Amendment Act (no. 2) of 1907, which repealed section 115 of the 1905 act and replaced it with a new section 25 , modelled very closely on the clauses in the Arbitration Act which empowered the Minister for Railways to enter into agreements with the ASRS and provided for disputes to be referred to the Arbitration Court. The Seddonville union made an agreement under this clause in 1909, and so did the small Westland Certificated Engine-drivers and Firemen's Union. At the second state mine at Runanga however, the State Miners Union ignored the clause and cancelled its registration under the Arbitration Act in 1909, as did the Seddonville union in 1911. Both unions were part of the "Red" Federation of Labour, which preferred direct bargaining with the employer to dealings with the Arbitration Court. After the defeat of the 1913 waterfront strike the mining unions were reintegrated into the arbitration system, and in May 1914 the Arbitration Court for the first time issued an award binding the Point Elizabeth and Liverpool State Collieries Union at Runanga and the State Coal-mines Department.

While the ASRS never exercised its right to take a claim to the Arbitration Court, it took advantage of its registration under the Arbitration Act to check the recognition of rival unions in the railway service. In 1908 dissatisfied ASRS members formed the NZ Locomotive Enginedrivers, Firemen and Cleaners Associations (EFCA) but, because the Arbitration Act named only the ASRS as "the registered society" in the railway service, the EFCA was forced to register under the Trade Unions Act, which gave it no official recognition and no access to the Arbitration Court.

There is no evidence that the EFCA intended to take a case to the Arbitration Court. What it wanted was to be entitled to direct access to the minister, but to achieve this it had to break the monopoly of the ASRS by being named on equal terms in the Arbitration Act. In 1909, and again in 1910, the EFCA petitioned Parliament seeking official recognition. It achieved de facto recognition in 1911, but it took another ten years before the Arbitration Act was amended to give the EFCA equal status with the ASRS. Another breakaway from the ASRS, the Railway Tradesmen's Association (RTA) formed in 1924, gained recognition in the Arbitration Act a year later. Neither the EFCA nor the RTA ever lodged claims with the Arbitration Court but. like the ASRS, they kept alive their registrations under the Arbitration (later Industrial Relations) Act.

In 1912 a Public Service Act placed staff in the public service proper and in the Post and Telegraph Department under the control of a Public Service Commissioner. Parliament 
continued to appropriate the necessary funds and it retained the right to increase or reduce the total of all salaries in any ratio desired, but the Commissioner was made responsible for classifying the public service (post office staff had been classified as early as 1890) and for grading each employee. After the war, when government salaries failed to keep step with rises in the cost of living, the Public Service Association (PSA) explored the possibilities of registration under the Arbitration Act. "I am prepared to put you all on the Arbitration Act". Prime Minister Massey told a PSA deputation in 1920, which asked for higher salaries (Public Service Journal May 1920). After two pay cuts in 1922, registration under the Arbitration Act was again put forward as a solution. The PSA conference in 1923 discussed a remit along these lines, but there was little support for it. Like the ASRS, public servants feared that a switch to the arbitration system would entail the loss of existing privileges, notably superannuation and appeal boards. What they wanted, a delegate told the 1923 conference, was not necessarily access to the Arbitration Court but access to some kind of tribunal "to deal with questions relating to working conditions and salaries in the public service - an independent body apart from the Public Service Commissioner or the government" (ibid Sept 1923).

The Government was not prepared to set up independent tribunals in the public sector but in May 1924, after the collapse of the national rail strike, it offered the ASRS the services of the Arbitration Court to inquire into its wage claims and make recommendations to the Minister of Railways. In fact, the Government gave the ASRS four alternatives to choose from: the Arbitration Court as constituted, the Arbitration Court with one additional representative each from the union and from the department, a Royal Commission, or a petition to Parliament. The ASRS officials rejected the first option out of hand, but they accepted the second option of an enlarged Arbitration Court sitting as a Board of Inquiry. The Government implemented the recommendations made by a majority of this five-man board, over the objections of the two employee representatives. This was as close as the ASRS came to having its claims considered, but not determined, by members of the Arbitration Court.

The Post and Telegraph Employees Association decided in 1928 in favour of putting postal staff under the Arbitration Act, but the PSA was more cautious. What it asked for was "full and free opportunity to place our grievances and claims before an impartial and judicial body" (Ibid Feb 1928). In 1935, after government employees had suffered further pay cuts during the depression, the Central Committee of the Combined State Organisations affirmed the principle "that an independent tribunal should be available for the determination of emoluments and conditions in the public service", but the Government ignored this request (Ibid Aug 1935).

The Labour Government, which came to power at the end of 1935, once again restored direct ministerial control over the government railways. It also set up tripartite Staff Tribunals in the railway service, but with purely advisory powers. Echoing Seddon's words in 1901, the new Minister of Public Works, Bob Semple, told Parliament in 1936: "We are directly responsible to the taxpayers and while we are here, we are not going to delegate our powers to Boards or Commissions or Committees" (Parliamentary Debates v. 244 p. 127,3 April 1936). Seven years later the Labour Government was changing its mind, at least where wage-fixing was concerned. The ASRS and RTA were conducting a campaign in 1943 in support of higher pay and the removal of so-called "wage anomalies". They enlisted the support of the Federation of Labour (FOL) and in their joint discussions with cabinet ministers there surfaced the idea of an independent mandatory wage-fixing tribunal for railway staff, patterned on the Arbitration Court. In December 1943 the acting Prime Minister Nash formally offered such a tribunal to the railway unions. The FOL apparently would have preferred bringing the entire state service under the Arbitration Act; the Government was agreeable to this, but the railway unions preferred to have their own tribunal, with members experienced in railway matters assisting a jointly agreed chairman.

In March 1944, when speaking to the amending bill which set up the Government Railways Industrial Tribunal, Prime Minister Fraser spelled out the new policy: "The Government", he said, "ought not to be in a different position, essentially, from other employers... There is no reason at all why, as an employer, it should not be subjected to the decisions of the bodies that decide industrial conditions generally" (ibid v. 264 p. 681, 27 March 1944). Fraser had already offered similar tribunals to the post office and public service unions. The post office union was content with an advisory tribunal, but the PSA rejected the offer because it expected better results from direct dealings with the Public Service Commissioner in a joint Consultative Committee.

The subsequent events can only be sketched in flimsy detail, but the trend has been for ever closer involvement of state workers with the private sector industrial relations system. Major 
pointers along this road were the establishment of a whole range of wage-fixing tribunals in the state sector; the institution of ruling rates surveys which measured wage levels and movements in the private sector which were were then translated into salary rises for state employees; the passing on of Arbitration Court general wage orders to state workers and the right given to the PSA and to railway unions to make submissions in the Arbitration Court at general wage order hearings (1952); the establishment of an across-the-board State Services (later Public Sector) Tribunal in 1969, with a judge of the Arbitration Court as chairman; and the transfer of groups of state employees to the private sector wage-fixing system.

The first major transfer of this kind took place in 1972, when mental hospitals were placed under the control of hospital boards and 1800 state tradesmen and related personnel became subject to private sector awards. In 1987 this movement gained momentum with the tranformation of entire government departments into state-owned corporations. New legislation abolished the Public Sector Tribunal and the Police Staff Tribunal, substituting in each case a new Arbitration Commission, which rules supreme in both sectors. On the other hand, a clause in the Labour Relations Act of 1987 (s 367) deprived the three railway unions of their longstanding right of registration.

To sum up: When compulsory arbitration became law in 1895, state employees retained their separate pay-fixing arrangements. In the years that followed they negotiated, wherever possible, salaries and conditions directly with their employing authorities: departmental heads, the Public Service Commissioner, and cabinet ministers, not excluding the occasional petition to Parliament. The three railway unions which were registered under the Arbitration Act made no use of their right of access to the Arbitration Court, and the compulsory arbitration system was virtually irrelevant to government employees. In the 1920 s however, they began to clamour for access to independent pay determination, which they achieved in the form of a parallel system of sector tribunals patterned on the Arbitration Court.

These tribunals have now disappeared, but staff in the core (i.e. not corporatised) public service have retained the right to refer disputed pay claims to an independent body, the new Arbitration Commission. It is somewhat ironical that compulsory arbitration was abolished in the private sector in 1984, but survived, for the time being at least, in parts of the state sector. The Government's "Buff Paper" however, which was published in 1986, anticipates that this anomaly will not continue for long. "To enable .... agreements to be determined by a process of independent arbitration forced on the employer would be to risk seriously inhibiting the autonomy of management", wrote the authors of the report (Pay fixing in the state sector, 1986, p. 42 ), and they proposed to replace compulsory arbitration in the state sector by "registered agreements enforceable through the same mechanisms applying to the private sector" (ibid p. $54)$.

\section{References}

Annual conference of Trades and Labour Councils of New Zealand (1898) Wellington, New Zealand Times.

Holt, J (1986) Compulsory arbitration in New Zealand Auckland, Auckland University Press.

Pay fixing in the state sector (1986) Wellington, Government Printer.

Reeves W (1902) State experiments in Australia \& New Zealand London, Grant Richards.

Trades and Labour Council of New Zealand (1901) Report of annual conference Wellington, Evening Post. 